\title{
Serodeteksi Brucellosis dengan Metode Rose Bengal Test dan Complement Fixation Test pada Sapi Perah di Banyuwangi
}

\section{Serodetection of Brucellosis using Rose Bengal Test and Complement Fixation Test Method in Dairy Cattle in Banyuwangi}

\author{
Estiary Wilujeng1*, Suwarno², Ratih Novita Praja ${ }^{2}$, Iwan Sahrial Hamid ${ }^{3}$, Maya \\ Nurwartanti Yunita ${ }^{4}$, Prima Ayu Wibawati ${ }^{5}$ \\ ${ }^{1}$ Bachelor of Veterinary Medicine, ${ }^{2}$ Department of Microbiology, ${ }^{3}$ Department of Basic Veterinary Medicine, \\ ${ }^{4}$ Department of Pathology, ${ }^{5}$ Department of Veterinary Public Health \\ Faculty of Veterinary Medicine, Universitas Airlangga, \\ UNAIR-C Campus Mulyorejo, Surabaya, Jawa Timur, Indonesia 60115 \\ Telp. (031)5993016, Fax: (031)5993015 \\ *Corresponding author: estiary.wilujeng-2016@fkh.unair.ac.id
}

\begin{abstract}
Abstrak
Tujuan penelitian adalah untuk mendeteksi adanya antibodi dari Brucella pada ternak sapi perah betina di Banyuwangi menggunakan uji Rose Bengal Test (RBT) untuk uji cepat dan dikonfirmasi dengan menggunakan Complement Fixation Test (CFT). Sebanyak 84 sampel dari 516 sapi perah betina di Banyuwangi, kemudian diambil secara acak. Sampel yang diambil berasal dari serum sapi perah betina. Hasil penelitian ditemukan dua sampel yang dinyatakan positif Brucellosis dengan uji RBT dan CFT. RBT merupakan uji screening yang dapat memberikan hasil positif palsu, dan kemudian dikonfirmasi dengan uji CFT untuk melihat titer hasil vaksin atau infeksi alam. Hasil positif pada uji RBT memiliki hubungan dengan hasil titer CFT karena titer antibodi pada RBT dapat diukur dari derajat aglutinasi yang terbentuk. Hasil seropositif penyakit Brucellosis di Banyuwangi sebesar $2 \%$.
\end{abstract}

Kata kunci: Brucellosis, Rose Bengal Test, Complement Fixation Test, Banyuwangi

\section{Abstract}

This study aimed to detect the presence of antibodies of Brucella in dairy cattle in Banyuwangi using Rose Bengal Test (RBT) to screening then confirmed by Complement Fixation Test (CFT). A total of 84 samples from 516 dairy cattle of the Banyuwangi were taken by random sampling. The samples in this reasearch were collected from serum of dairy catlle. The results were found that 2 sample positive Brucellosis that were tested by RBT and CFT. RBT was a screening test that give a false positif then confirmed using CFT to show difference titer result of vaccinated and natural infection. Positive result of RBT have a relation with CFT titer due to antibody titer in RBT can measure with degrees of aglutination. The presence of the Brucellosis in Banyuwangi was $2 \%$.

Keywords: Brucellosis, Rose Bengal Test, Complement Fixation Test, Banyuwangi

Received: 7 Januari 2020

Revised: 23 Januari 2020

Accepted: 10 Februari 2020

\section{PENDAHULUAN}

Brucellosis merupakan penyakit infeksius yang dapat menyebabkan kerugian bagi manusia, hewan, serta sosial-ekonomi (Garcell et al., 2016). Menurut Kementan (2013), Brucellosis bersifat zoonosis dan termasuk salah satu Penyakit Hewan Menular Strategis (PHMS). Brucellosis pada ternak sering ditemukan pada masalah reproduksi dan berdampak pada kerugian ekonomi (Mota et al., 2016). Gangguan reproduksi dapat menyebabkan kegagalan kelahiran dan meningkatkan biaya pengobatan (Ilham, 2016). Kerugian ekonomi Indonesia yang ditimbulkan penyakit Brucellosis pada sapi tiap tahun mencapai 3.6 trilyun (Basri dan Sumiarto, 2017). Brucellosis pada sapi merupakan penyakit menular yang sering 
disebabkan oleh bakteri Brucella abortus (Wareth et al., 2017). Brucellosis dapat menyebabkan keguguran pada hewan usia kebuntingan 6-9 bulan, dan menular ke manusia serta menimbulkan gejala klinis seperti sakit kepala, demam intermitten, myalgia, dan gangguan pencernaan (Praja dkk., 2017).

Berdasarkan hasil uji dari Balai Besar Veteriner Wates tahun 2018 terdapat tiga provinsi di Pulau Jawa yang dinyatakan positif Brucellosis, yaitu Provinsi Jawa Timur, Jawa Tengah dan Daerah Istimewa Yogyakarta dengan total sampel positif yang didapatkan dari ketiga provinsi tersebut adalah sebesar 285 sampel. Lebih dari 100 sampel ditemukan di Jawa Timur. Tingginya kasus Brucellosis menjadikan prioritas utama dalam program pegendalian penyakit (Samkhan dkk., 2015).

Banyuwangi merupakan kota di Jawa Timur yang belum bebas dari kasus Brucellosis. Brucellosis ditemukan di Banyuwangi pada tahun 2017 sebesar 3\% pada sapi perah (Winarsih., 2018). Tahun 2018 sebanyak 3\% sampel dinyatakan positif dengan uji RBT di kecamatan Purwoharjo (Dwi dkk., 2018). Berdasarkan data statistik dari Dinas Peternakan, Banyuwangi mempunyai jumlah populasi ternak sapi perah sebesar 698 ekor pada tahun 2018. Jumlah ini tergolong sedikit apabila dibandingkan dengan kota lain seperti Pasuruan, Malang, Blitar dan Kediri. Populasi ternak yang sedikit dan gejala penyakit yang asimtomatis seringkali membuat penyakit Brucellosis kurang diperhatikan. Letak geografis dan luasnya wilayah Banyuwangi mengakibatkan sulitnya pengawasan lalu lintas ternak, hal ini yang menyebabkan hingga saat ini upaya pengendalian dan penanggulangan pernyakit Brucellosis masih belum merata. Penelitian bertujuan untuk mendeteksi kasus Brucellosis di Kabupaten Banyuwangi dengan metode screening menggunakan RBT dan dikonfirmasi dengan menggunakan CFT.

\section{METODE PENELITIAN}

Penelitian dilakukan dalam dua tahapan, yakni tahap pengambilan sampel dan tahap pemeriksaan serologis. Pengambilan sampel dilakukan di Kecamatan Pesanggaran, Bangorejo, Purwoharjo, Tegaldlimo, Muncar, Cluring, Gambiran, Srono, Genteng, Glenmore, Kalibaru, Songgon, Siliragung dan Licin. Uji RBT dilakukan di Laboratorium Instrumen Universitas Airlangga PSDKU di Banyuwangi dan pengujian CFT dilakukan di Balai Besar Veteriner (BBVet) Denpasar. Antibodi Brucella diamati dengan menggunakan dua tes. Pertama adalah uji screening dengan menggunakan RBT dan jika hasilnya positif maka dilanjutkan dengan uji konfirmasi yaitu menggunakan CFT (Samkhan dkk., 2015). Penelitian menggunakan sampel serum sapi perah betina dewasa secara random sebanyak 84 ekor dari 516 populasi sapi perah betina di Banyuwangi.

Alat yang digunakan dalam pengujian ini adalah tabung vacutainer non EDTA (OneMed) 5 mili, jarum venoject (BD Vacutainer ${ }^{\circledR}$ ) ukuran $21 \mathrm{G}$, holder venoject (BD Vacutainer ${ }^{\circledR}$ ), rak tabung reaksi, ice box (Lion $\mathrm{Star}^{\circledR}$ ), ice gel $\left(\mathrm{Gabag}^{\mathrm{TM}}\right)$, freezer $\left(\mathrm{GEA}^{\circledR}\right)$, centrifuge (HettichEBA 20), masker (OneMed), sarung tangan (Sensi ${ }^{\circledR}$, plat tetes, micropipet $\left(\right.$ Acura $\left.^{\circledR}\right)$, microtube, yellow tip, microplate, Erlenmeyer, microshaker (Stuart $\left.{ }^{\mathrm{TM}}\right)$, incubator (Memmert), dan waterbath (Memmert).

Bahan yang digunakan adalah kertas label, alkohol 70\% (OneMed) dan kapas (OneMed), Kit RBT Pusvetma (antigen Brucella, serum kontrol positif dan serum kontrol negatif)), CFT buffer $\left(\mathrm{Oxoid}^{\circledR}\right)$, Larutan Alsevers, hemolisin, komplemen darah marmut (IDvet), akuades, dan eritrosit domba.

\section{Pengambilan Sampel Serum}

Sampel diambil melalui vena jugularis (pada bagian leher) dan vena coccigea (pada bagian ekor) dengan menggunakan venoject. Sampel dimasukkan dalam tabung vacutainer dan diberi label, kemudian dimiringkan agar serum terpisah. Serum didapatkan setelah sampel darah didiamkan selama 3-4 jam. Serum kemudian dipindahkan ke dalam microtube dan diberi label. Pengambilan sampel serum untuk setiap sapi perah menggunakan tabung dan pipet yang 
berbeda agar terhindar dari kontaminasi. Serum disimpan di dalam freezer dengan suhu $-20^{\circ} \mathrm{C}$.

\section{Metode Rose Bengal Test (RBT)}

Prosedur pengerjaan uji RBT disesuaikan dengan standar yang berlaku di PUSVETMA. Standar penentuan nilai pada uji RBT terdiri dari dua kategori penilaian, yaitu hasil negatif (-), apabila tidak tejadi aglutinasi dan warna serum tetap homogen yakni ungu kemerahan, dan hasil positif (+) ditunjukkan dengan terbentuknya aglutinasi berupa bentukan seperti pasir. Hasil uji positif pada metode RBT dibagi menjadi tiga kategori yakni, apabila terbentuk aglutinasi halus dan tepi dikelilingi dengan partikel halus yang membentuk garis putus-putus, maka dianggap positif satu (+). Apabila aglutinasi terlihat seperti butiran pasir dan membentuk partikel aglutinasi dengan tepi pinggiran lebar, maka nilainya adalah positif dua $(++)$. Nilai positif tiga $(+++)$ didapat ketika terjadi aglutinasi yang sempurna, kasar, dan batas sangat jelas (OIE, 2018).

\section{Metode Complement Fixation Test (CFT)}

Pengujian dengan metode CFT dilakukan dengan menggunakan sampel serum sapi yang positif pada uji RBT. Uji CFT yang dilakukan berfungsi sebagai uji konfirmasi. Pengujian serologik dengan menggunakan metode CFT disesuaikan dengan prosedur standar BBVet Denpasar. Hasil uji CFT adalah sesuai dengan pengenceran serum yang tertinggi yang menunjukkan reaksi positif, yakni tidak terjadi lisis. (Ghurafa dkk, 2019; OIE, 2018). Pembacaan hasil uji pada uji CFT berdasarkan derajat hemolisis, yakni negatif atau $100 \%$ hemolisis yaitu apabila sel darah mengalami lisis, cairan berwarna merah muda dan tidak terdapat endapan eritrosit didasar cawan. Positif $1(+)$ atau $75 \%$ hemolisis ketika terjadi hemolisis sempurna, cairan dalam cawan berwarna merah dan terdapat sedikit eritrosit didasar cawan. Positif $2(++)$ atau $50 \%$ hemolisis ketika sebagian besar terjadi hemolisis, cairan berwarna merah dan terdapat endapan eritrosit yang agak melebar dengan tepi yang rata. Positif $3(+++)$ atau $25 \%$ hemolisis ketika sebagian eritrosit tidak lisis, warna cairan agak merah dan terlihat jelas adanya endapan eritrosit. Positif $4(++++)$ atau $0 \%$ hemolisis yakni ketika tidak terjadi hemolisis, cairan nampak bening dan terlihat jelas endapan eritrosit dengan batas pinggir yang nyata (Alhabbab, 2018).

\section{Analisa Data}

Deteksi antibodi Brucellosis dihitung dengan melihat jumlah sampel positif dan dibandingkan dengan jumlah total sampel yang dikumpulkan di Kabupaten Banyuwangi kemudian dikalikan dengan $100 \%$.

\section{HASIL DAN PEMBAHASAN}

Hasil uji screening terhadap 84 sampel darah yang diambil di 14 Kecamatan di Kabupaten Banyuwangi dengan menggunakan metode RBT dan CFT didapatkan hasil positif sebanyak 2 sampel (Tabel 1). Hasil positif terlihat ketika terjadi aglutinasi pada sampel serum yang dicampur dengan Antigen RBT dan membentuk gumpalan halus seperti pasir. Sampel positif hasil pengujian RBT memiliki kode sampel LCN/I/7 dan LCN/I/13. Hasil pemeriksaan positif pada uji RBT didapatkan pada sapi yang berjenis Friesian Holstein umur 36 bulan dan berjenis kelamin betina dan berdasarkan riwayat yang telah diperoleh dari pemilik sapi bahwa salah satu sapi perah tersebut pernah mengalami keguguran dan keduanya telah dilakukan vaksinasi dengan vaksin S19 pada bulan Juni. Hasil yang diperoleh menunjukan bahwa serum dan antigen menunjukan reaksi positif +++ pada sampel serum dengan kode LCN//I/7 dan LCN//I/13 yang ditunjukan dengan adanya agultinasi yang sempurna, kasar, dan batas sangat jelas (Gambar 1). Sampel tersebut kemudian dilanjutkan dengan tes konfirmasi menggunakan metode CFT.

Pengujian dengan menggunakan metode CFT dilakukan di BBVET Denpasar. Sampel yang digunakan untuk uji CFT yakni dua sampel yang dinyatakan positif pada uji RBT. Berdasarkan hasil uji dari BBVet Denpasar dapat dinyatakan bahwa kedua sampel tersebut menunjukkan hasil positif pada uji CFT. Hasil CFT menunjukkan derajat hemolisis $25 \%$ atau 
Tabel 1. Hasil uji RBT dan CFT pada 14 Kecamatan di Kabupaten Banyuwangi

\begin{tabular}{lccc}
\hline \multicolumn{1}{c}{ Kecamatan } & Jumlah Sampel & RBT & CFT \\
\hline Pesanggaran & 4 & - & - \\
Bangorejo & 11 & - & - \\
Purwoharjo & 23 & - & - \\
Tegaldlimo & 1 & - & - \\
Muncar & 2 & - & - \\
Cluring & 2 & - & - \\
Gambiran & 2 & - & - \\
Srono & 1 & - & - \\
Genteng & 4 & - & - \\
Glenmore & 2 & - & - \\
Kalibaru & 16 & - & - \\
Songgon & 4 & - & - \\
Siliragung & 2 & - & - \\
Licin & 10 & 2 & 2 \\
\hline
\end{tabular}
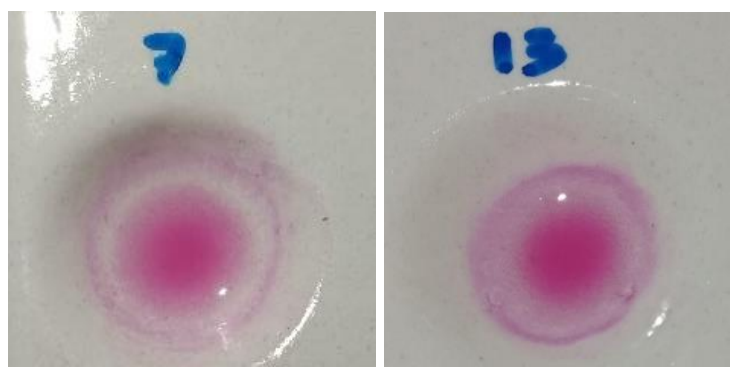

Gambar 1. Hasil pemeriksaan serum yang di uji dengan RBT menunjukan reaksi positif +++ yang ditunjukan adanya agultinasi yang sempurna, kasar, dan batas sangat jelas

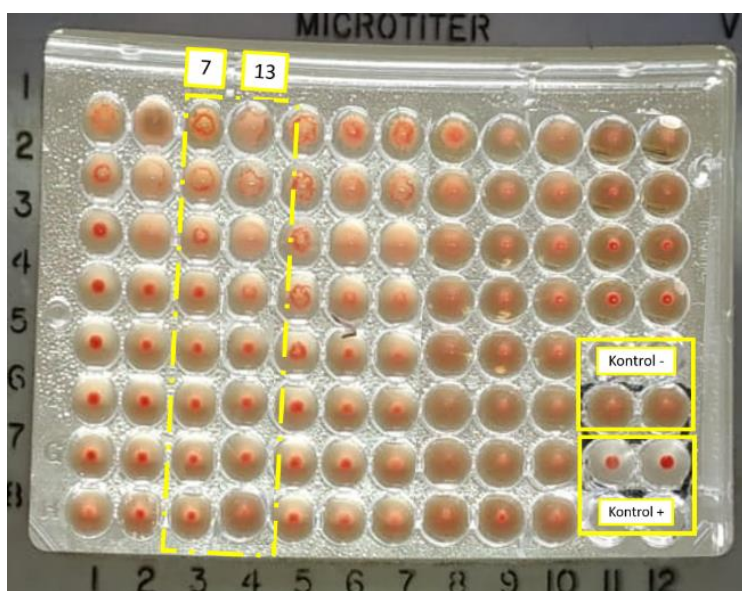

Gambar 2. Hasil pemeriksaan serum yang di uji dengan metode CFT. Sampel 7 dan 13 terlihat positif +++ atau $25 \%$ hemolisis yang ditandai dengan eritrosit tidak lisis dan warna cairan agak merah. Kontrol positif atau $0 \%$ hemolisis ketika tidak terjadi hemolisis, cairan nampak bening dan terlihat jelas endapan eritrosit. Kontrol negatif atau 100\% hemolisis yakni ketika cairan berwarna merah dan tidak terdapat endapan eritrosit didasar cawan

disebut dengan positif +++ yang ditandai dengan sebagian eritrosit tidak lisis, warna cairan agak merah dan masih terlihat jelas adanya endapan eritrosit. Titer CFT yang didapat pada sapi kode
LCN//I/7 dan LCN//I/13 adalah 1/128 dan 1/64 (Gambar 2). Pemeriksaan sampel secara keseluruhan dari 84 sampel serum terdapat 2 sampel yang di nilai positif dalam uji RB) dan 
CFT. Persentase dari keseluruhan sampel yang diperoleh pada bulan Desember 2019 menunjukan hasil positif sebesar $2 \%$ yaitu 2 sampel dari 84 sampel diperoleh.

Uji RBT merupakan rapid test yang berfungsi untuk mendeteksi adanya antibodi Brucella dalam serum (Alamian et al., 2019). Apabila sapi terinfeksi Brucella, maka tubuh akan menghasilkan antibodi yang berfungsi untuk melawan adanya infeksi. Hasil positif pada uji RBT ditandai dengan aglutinasi yang tampak seperti butiran pasir berwarna merah muda (Onsa et al., 2018). Aglutinasi terjadi ketika ikatan antara Antigen RBT dengan antibodi berada dalam serum (Al Tahir., 2016). Adanya ikatan tersebut ditandai dengan terbentuk gumpalan-gumpalan pada serum (Besung, 2015).

Secara umum respon imun yang dihasilkan oleh hewan dapat ditemukan dalam beberapa jenis yaitu $\operatorname{IgM}, \operatorname{IgG} 1, \operatorname{IgG} 2$, dan $\operatorname{IgA}$ (Kaltungo et al., 2014). IgM merupakan antibodi yang muncul pertama kali ketika terjadi infeksi. Antibodi ini juga dapat diperoleh dari proses vaksinasi (Mohamed et al., 2015). IgG2 dan IgA terdapat dalam jumlah yang sedikit dan biasanya setelah enam bulan akan menghilang, namun kadar IgM dan IgG1 masih tetap ada meskipun dalam jumlah yang rendah (Neta et al., 2010). Pada kejadian infeksi yang menahun atau dalam kurun waktu yang lama kadar antibodi IgG1 lebih tinggi dari kadar antibodi IgM, sehingga deteksi terbaik adalah dengan menggunakan IgG1 (Poester et al., 2010).

Brucella tergolong strain halus atau smooth lipopolisakarida (S-LPS) yakni pada B. abortus, $B$. melitensis dan B. suis, memiliki virulensi yang tinggi karena pada LPS-nya mengandung komponen rantai $\mathrm{O}$ yang merupakan antigen paling dominan dan dapat terdeteksi pada hewan maupun manusia yang terinfeksi Brucellosis (Noor, 2006). Vaksin yang digunakan dalam program pengendalian penyakit Brucellosis adalah vaksin hidup yang dilemahkan yakni S19 dan RB51. Vaksin strain 19 memiliki strain halus (smooth) yang mengandung rantai $\mathrm{O}$, sapi yang divaksin dengan S19 akan terdeteksi positif karena dapat menstimulasi terbentuknya antibodi terhadap antigen pada rantai $\mathrm{O}$. Hal ini menyebabkan vaksin S19 sulit dibedakan antara antibodi hasil vaksinasi dan hasil infeksi alam (Martins et al., 2009). Strain RB51 merupakan strain kasar atau (rough) yang tidak memiliki rantai $\mathrm{O}$, sehingga ternak yang divaksin dengan strain RB51 tidak memproduksi antibodi terhadap antigen pada rantai $\mathrm{O}$ yang terdeteksi pada uji serologi brucellosis (Cardoso et al., 2006). Vaksin RB51 merupakan vaksin yang digunakan untuk menggantikan vaksin S19, karena memiliki proteksi yang sama namun tidak menimbulkan reaksi pasca vaksinasi (Suwarno dkk., 2014).

Antigen Brucella yang digunakan pada pemeriksaan RBT memiliki koloni smooth yang diwarnai dengan pewarna Rose Bengal, dengan larutan penyangga sampai dengan $\mathrm{pH}$ 3,65. Kondisi pH yang netral dapat mengukur keberadaan IgM, IgG1 dan IgG2. RBT memiliki kadar pH 3,65 yang dapat mengakibatkan inaktivasi sementara dari $\operatorname{IgM}$ dan hanya mengukur IgG1 (Kaltungo et al., 2014). Hasil tes RBT dapat memberikan reaksi positif-palsu yang disebabkan oleh adanya vaksinasi oleh vaksin S19 (Asakura, 2018). Hal ini menyebabkan pemeriksaan serum dengan menggunakan RBT tidak bisa membedakan reaksi terhadap vaksin S19 oleh karena itu perlu adanya uji konfirmasi menggunakan CFT yang dapat menghitung titer antibodi dan membedakannya dengan hasil vaksinasi (Addis dan Desalegn, 2018).

Sebanyak dua sampel yang positif RBT dibawa ke Balai Besar Veteriner Denpasar (BBVET Denpasar) untuk dilakukan uji CFT. Uji CFT hanya mendeteksi IgG1, sebab IgM yang berada pada serum sebelum diuji akan diinaktivasi dengan pemanasan pada prosedur pengujian CFT. IgM akan mengalami inaktivasi pada suhu $56-58^{\circ} \mathrm{C}$ selama 30 menit (Kaltungo et al., 2014). Hasil positif pada CFT ditentukan oleh komplemen yakni protein kompleks yang akan bereaksi apabila terdapat ikatan antara antigen dan antibodi. Komplemen yang telah mengikat antigen dan antibodi akan menyebabkan tidak terjadinya hemolisis, yang menandakan sampel serum bereaksi positif atau mengandung antibodi Brucella, sedangkan reaksi negatif terjadi apabila terjadi hemolisis yang 
menandakan serum tidak mengandung antibodi Brucella. (Galinska dan Jerzy., 2013).

Hasil titer uji CFT dihitung dengan melihat pengenceran serum tertinggi yang menunjukkan reaksi positif, yakni tidak terjadi lisis. Titer CFT dapat membedakan antibodi yang berasal dari hasil vaksin apabila titer yang didapat adalah lebih dari 1/6 atau setara dengan 30 ICFTU/ml setelah $3-6$ bulan pasca vaksinasi (OIE, 2018). Hasil positif pada uji RBT berhubungan dengan derajat infeksi, karena pada uji ini titer antibodi diukur dengan melihat derajat aglutinasi antara antigen dan antibodi. Uji RBT dengan hasil positif (+++) menandakan adanya antibodi Brucella yang tinggi (Rohyati dkk., 2018). Semakin tinggi titer CFT maka semakin tinggi antibodi Brucella dalam serum (Rostandi, 2017). Pada hasil penelitian yang telah dilakukan dapat dilihat bahwa hasil positif +++ pada RBT memiliki titer CFT yang tinggi yakni diatas 1/64 dan pembacaan hasil positif CFT nya adalah positif +++. Perbedaan hasil titer dapat disebabkan oleh perbedaan jumlah antibodi Brucella yang disebabkan karena umur, dosis infeksi bakteri, rute infeksi, dan status kekebalan host (Kaltungo et al., 2014; Pradika et al., 2019).

Terdapat hasil ternak bunting yang mengalami abortus, namun pada uji serologi bernilai negatif. Kasus ini dapat disebabkan karena kemungkinan penyakit reproduksi lain seperti leptospirosis, trichomoniasis, dan Infection Bovine Rhinotracheitis (IBR) (Adjid., 2004). Kasus Brucellosis juga ditemukan di Jawa timur sebanyak 231 kasus oleh BBVet Wates pada tahun 2018 (BBVet Wates., 2019), selain itu juga telah ditemukan sekitar 2\% kasus positif Brucellosis dengan metode RBT dan CFT di Kota Bogor dan Bandung Barat pada tahun 2019 (Ghurafa et al., 2019).

\section{KESIMPULAN}

Disimpulkan bahwa ditemukan antibodi Brucella pada sapi perah yang dibuktikan dengan terjadinya reaksi aglutinasi berupa pasir halus pada uji RBT, dan didapatkan titer 1/64 dan 1/128 pada uji CFT. Sampel yang dinyatakan positif Brucellosis sebesar 2\% dari total sampel yang telah diambil yaitu 2 sampel dari 84 sampel yang telah diteliti. Terdapat hubungan antara metode RBT dan CFT yang dapat dilihat melalui penilaian hasil positif RBT yang dapat menunjukkan titer antibodi melalui derajat aglutinasi.

\section{UCAPAN TERIMA KASIH}

Peneliti mengucapkan terimakasih kepada Universitas Airlangga PSDKU Banyuwangi, Balai Besar Veteriner Denpasar, Dinas Pertanian Kabupaten Banyuwangi dan para peternak serta dokter hewan setempat atas izin dan fasilitas yang disediakan sebagai penunjang penelitian.

\section{DAFTAR PUSTAKA}

Addis, S.A, Desalegn, A.Y. 2018. Comparative Seroepidemiological Study of Brucellosis in Sheep under Smallholder Farming and Governmental Breeding Ranches of Central and North East Ethiopia Shimeles Abegaz Addis and Andualem Yimer Desalegn. Hindawi J. Vet. Med., 48, 1-12.

Adjid, R.M.A. 2004. Strategi Pengendalian Penyakit Reproduksi Menular untuk Meningkatkan Efisiensi Reproduksi Sapi Potong. Wartazoa, 14(3), 125-132.

Alamian, S., Dadar, M., Soleimani, S., Behrozikhah, A. M., Etemadi, A .2019. A Case of Identity Confirmation of Brucella abortus S99 by Phage Typing and PCR Methods. Arch. Razi Ins., 74(2), 127-133.

Alhabbab, R.Y. 2018. Basic Serological Testing, Techniques in Life Science and iomedicine for the Non-Expert. Switzerland: Springer, pp: 63-75.

Al Tahir, M.O. 2016. Estimation of Brucella Antibodies among Febrile Patients attending Al Matamma Hospital (Sudan). Afr. J. Med. Sci., 1(1), 1-7. 
Asakura, S., 2018. Exploration of Sustainable and Affordable Control Options of Bovine Brucellosis in The Endemic Zone in Tanzania [Doctoral Dissertation]. Universitas Rakuno Gakuen.

Basri, C., Sumiarto, B. 2017. Taksiran Kerugian Ekonomi Penyakit Kluron Menular (Brucellosis) pada Populasi Ternak di Indonesia. Jurnal Veteriner, 18(4), 547-556.

[BBVet Wates] Balai Besar Veteriner Wates. 2019. Peta Penyakit Hewan dan Kesmavet tahun 2018. Direktorat Jenderal Peternakan dan Kesehatan Hewan. Kementerian Pertanian RI.

Besung, I.N.K., Suwiti, N.K., Suarjana, I.G. 2015. Seroepidemiologi Brucellosis pada Sapi Bali di Nusa Tenggara Barat sebagai Upaya Deteksi Dini Kejadian Penyakit. Fakultas Kedokteran Hewan. Universitas Udayana.

Cardoso P.G., Macedo, G. C., Azevedo, V., Oliveira, S.C. 2006. Brucella spp Noncanonical LPS: Structure, Biosynthesis, and Interaction with Host Immune System. J. BioMed Central, 5(13), 1-11.

Dwi, W.K., Tyasningsih, W., Praja, R.N., Hamid, I.S., Purnama, M.T.E. 2018. Deteksi Antibodi Brucella pada Sapi Perah di Kecamatan Purwoharjo Kabupaten Banyuwangi dengan Metode Rose Bengal Test (RBT). Jurnal Medik Veteriner, 1(3), 142-147.

Galinska., E.M., Jerzy, Z. 2013. Brucellosis in humans - etiology, diagnostics, clinical forms. Ann. Agric. Environ. Med., 20(2), 233-238.

Garcell, H.G., Garcia, E.G., Pueyo, P.V., Martin, I.R., Arias, A.V., Serrano, R.N.A. 2016. Outbreaks of Brucellosis related to the consumption of unpasteurized camel milk. J. Infect. Pub. Health, 9(4), 523-527.
Ghurafa, R., Lukman, D., Latif, H. 2019. Indirect Enzyme Linked Immunosorbent Assay Sebagai Metode untuk Melacak Bruselosis pada Sapi Perah. Jurnal Veteriner, 20(1), 30-37.

Ilham, N. 2016. Kebijakan Pengendalian Harga Daging Sapi Nasional. Pusat Analisis Sosial Ekonomi dan Kebijakan Pertanian, 7(3), 211-221.

Kaltungo, B.Y., Saidu, S.N.A., Sacey, A.K.B., Kazeem, H.M.A. 2014. Review on Diagnostic Techniques for Brucellosis. Afr. J. Biotechnol., 13, 1-10.

[Kementan] Kementerian Pertanian. 2013. Keputusan Menteri Pertanian (Kepmentan) Nomor 4026/Kpts./OT.140/3/2013 tentang Penetapan Jenis Penyakit Hewan Menular Strategis. Jakarta (ID): Kementan.

Mohamed, G.E., Alaidan, A.A., Al-hakail, A.A. 2015. Host Response to Brucella Infection: Review and Future perspective. J. Infect. Develop. Countries, 9(7), 697-701.

Mota, A.L.A., Ferreira, F., Neto, J.S.F., Dias, R. A., Amaku, M., Grisi-Filho, J.H.H., Telles, E.O., Goncalves, V.S.P. 2016. Large-Scale Study of Herd-Level Risk Factors for Bovine Brucellosis in Brazil. Acta Tropica, 164, 226-232.

Neta, A.V.C., Mol, J.P.S., Xavier, M.N., Paixao, T.A., Lage, A.P., Santos, R.L. 2010. Pathogenesis of Bovine Brucellosis. Vet. J., 184, 146-155.

[OIE] Office International des Epizooties. 2018. Manual of Diagnostic Test and Vaccines for Terrestrial Animals: Brucellosis, pp: 355398.

Onsa, R.A.H., Hamid, F.M., Elshafie, E.I., Muna, E.A., Mohammed, G.E. 2018. Production of Modified Rapid Serum 
Agglutination Antigen for Sero-diagnosis of Contagious Bovine Pleuropneumonia (CBPP). J. Adv. Microbiol., 13(3), 1-7.

Poester, F.P., Nielsen, K., Samartino, L.E., Yu, W.L. 2010. Diagnosis of Brucellosis. Open Vet. Sci. J., 4, 46-60.

Pradika, A.Y., Chusniati, S., Purnama, M.T.E., Effendi, M.H., Yudhana, A., Wibawati, P.A. 2019. Uji Total Escherichia coli pada Susu Sapi Segar di Koperasi Peternak Sapi Perah (KPSP) Karyo Ngremboko Kecamatan Purwoharjo Kabupaten Banyuwangi. Jurnal Medik Veteriner, 2(1), 1-6.

Praja, R.N., Handijatno, D., Koesdarto, S., Yudhana, A. 2017. Karakterisasi Protein VirB4 Brucella abortus Isolat Lokal dengan Teknik Sodium Dodecyl Sulfate Polyacrylamide Gel Electrophoresis. Jurnal Veteriner, 18(3), 416-421.

Rohyati, E., Toelle, N.N., Hau, E.R. 2018. Uji Tapis Brusellosis Pada Sapi di RPH Oeba Kota Kupang dengan Menggunakan Uji RBT. Jurnal Partner, 23(2), 705-709.

Rostandi, Y.A. 2017. Penggunaan Kertas Saring (Filter Paper) sebagai Media Transpor Alternatif dalam Pengambilan Sampel Darah
Utuh pada Sapi untuk Pengujian Brucella Sp. [M.Sc. Thesis]. Institut Pertanian Bogor.

Samkhan., Ikaratri, R., Isnaini, M.F. 2015. Rencana Pendahuluan Road Map untuk Pembebasan Brucellosis di Pulau Jawa Tahun 2020. Buletin Laboratorium Veteriner, 15(4), 1-9.

Suwarno, Azizah, L.N., Samik, A. 2014. Deteksi Antibodi Brucella pada Sapi yang Dipotong di RPH Krian Kabupaten Sidoarjo dengan Rose Bengal Test (RBT). Veterinaria Medika, 7(2), 146-147.

Wareth, G., Melzer, F., El-Diasty, M., Schmoock, G., Elbauomy, E., Abdel-Hamid, N., Sayour, A., Neubauer, H. 2017. Isolation of Brucella abortus from a Dog and a Cat Confirms Their Biological Role in Re-Emergence and Dissemination of Bovine Brucellosis on Dairy Farms. Transbound. Emerg. Dis., 64(5), 27-30.

Winarsih, W.H. 2018. Penyakit Ternak yang Perlu Diwaspadai Terkait Keamanan pangan. Cakrawala Jurnal, 12(2), 208-221. 